\title{
Amazônia: as relações sociais sob o prisma da narrativa de Ferreira de Castro
} The Amazon: social relations under the prism of the narrative of Ferreira de Castro

\author{
Maria do Perpétuo Socorro Rodrigues Chaves \\ Débora Cristina Bandeira Rodrigues" \\ Talita de Melo Liralli
}

Resumo: $\bigcirc$ presente trabalho discute o pensamento de Ferreira de Castro e seu olhar sobre a Amazônia. $\bigcirc$ propósito do artigo é contribuir para os debates sobre a formação do pensamento social na Amazônia. O trabalho a ser abordado será a obra 'A Selva', escrita por Ferreira de Castro entre os períodos de 1910 e 1920. Importa ressaltar que não se trata de uma obra de cunho científico ou acadêmico, mas de um romance, no qual o autor relata suas experiências vividas nas trilhas dos seringais tradicionais da Amazônia, marcada pela expressão de suas percepções baseadas na observação de práticas locais que formam uma intrincada teia de relações sociais.

Palavras-chave: Amazônia. Cultura. Pensamento social.

Abstract: This paper discusses the thought of Ferreira of Castro and his view about the Amazonian region. The purpose of our work is to discuss the establishment of the social thought in the Amazon. The work to be viewed is 'A Selva', written by Ferreira de Castro between 1910 and 1920. 'A Selva' is not a scientific or academic work, but a romance, in which the author narrates experiences lived in the trails of the traditional rubber taping areas of the Amazon, marked by his own perceptions on sharp observation of the local practices that form complex network of social relationships.

Keywords: Amazonia. Culture. Social thought.

I Universidade Federal do Amazonas. Departamento de Serviço Social. Professora. Manaus, Amazonas, Brasil (socorro.chaves@ig.com.br).

II Universidade Federal do Amazonas. Manaus, Amazonas, Brasil (deb.band@gmail.com).

III Universidade Federal do Amazonas. Bolsista de Iniciação Tecnológica e Industrial CNPq. Manaus, Amazonas, Brasil (talitademelolira@ bol.com.br).

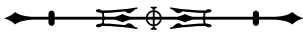




\section{INTRODUÇÃO}

A necessidade de realizar um ensaio sobre a obra de Ferreira de Castro está associada ao interesse em tratar as contribuições fornecidas por seu romance para formação do pensamento social na Amazônia, tendo em vista que os dilemas enfrentados na região assumiram relevância, sobretudo nas últimas três décadas. A visibilidade em torno das questões socioambientais e a necessidade de se repensar as ações do homem sobre o ambiente conduzem pesquisadores, cientistas e estudiosos, de um modo geral, a refletirem sobre as várias formas de interpretações que serviram para a constituição do pensamento difundido sobre a Amazônia e sua população.

Neste contexto, a formação do pensamento social sobre a Amazônia teve nos relatos dos primeiros viajantes expedicionários suas bases de constituição. Assim, a abordagem a ser realizada possui a finalidade de efetuar um passeio através da obra considerada, na atualidade, uma das grandes contribuições clássicas para a formação do pensamento social sobre a Amazônia, que retrata aspectos da região que precisam ser resgatados. Assim, entende-se que parte da cultura e da história do povo, que precisa ser conhecida e valorizada, encontra-se presente na obra 'A Selva', de Ferreira de Castro (1997).

Estudos e debates contemporâneos tomam como referência os relatos dos primeiros expedicionários que chegaram à Amazônia. É importante ressaltar que a obra de Ferreira de Castro guarda contribuições relevantes para compreensão da realidade contemporânea da Amazônia, haja vista que tal obra se constitui em fonte de pesquisa indispensável a todos que pretendem lançar um olhar mais aprofundado sobre esta região.

Em que pese as diversas possibilidades de interpretações possíveis da obra 'A Selva', encontrase expressa uma visão da Amazônia que aprisiona e embrutece o homem vindo da Europa ou de outro lugar "civilizado"; a selva é apresentada como um "ser" que possui vontade própria e reina sobre o homem, o qual se queda impotente diante da sua grandeza e magnitude.
A "selva" fecha-se sobre si mesma, os ramos formam verdadeiros muros, impedindo, dessa forma, que qualquer outro tipo de vida, que não seja a da própria natureza, permaneça por muito tempo, pois, fatalmente, torna-se semelhante a ela em sua "brutalidade".

autor encontra-se perplexo diante da grandeza dos rios e da floresta; seus olhos nunca presenciaram cena semelhante a que se lhes apresenta ao chegar ao "Novo Mundo". A obra inclui, principalmente, muitos indicativos referentes às relações sociais que se estabeleceram na Amazônia entre os períodos de 1910 e 1920, sobre o cenário do seringal tradicional que dominava o cenário amazônico nesse espaço de tempo, bem como as relações de produção e os agentes sociais entre si.

É importante destacar que a visão de mundo dos viajantes sobre a região influencia de modo marcante a forma de agir e de entender a Amazônia até os dias atuais. Assim, pode-se afirmar que a formação do pensamento social sobre a região e sua população é construída paulatinamente, tendo por base, em grande parte, os olhares e as interpretações exógenas sobre a mesma.

\section{Cenário da Amazônia sob o olhar de Ferreira de Castro}

\begin{abstract}
Essa incomensurável visão da terra desmesurada, que as árvores escondiam e eu aspirava dominar, concentrando-a na diminuta superfície dum livro, indo mais longe na pretensão do que os jívaros, que nesse mundo de sombras reduziam as cabeças humanas ao tamanho dum objeto de algibeira, ora me sussurrava esperanças, ora, desalentando-me, me dava piedade por mim, tão pequeno, tão insignificante perante ela me sentia (Charles Wagley, 1988).
\end{abstract}

Amazônia, para muitos, é sinônimo de "Eldorado", local onde há riquezas em abundância; em contraposição, para outros, representa o "inferno verde". Muitas vezes, estas interpretações estão carregadas de sentimentos contraditórios cuja contemplação deslumbra e amedronta os sentidos desafiantes à razão em seus 
parâmetros formais. A leitura de ambas as percepções está presente em 'A Selva'. Sentido e razão encadeiamse, apresentando o cenário contemplado nos seguintes termos:

[...] a Amazônia um imã na terra brasileira e para ela convergiam copiosas ambições dos quatro pontos cardeais, porque a riqueza se apresentava de fácil posse, desde que a audácia se antepusesse aos escrúpulos (p. 31).

Nesta mesma linha de pensamento, destaca-se o pensamento de Pe. João Daniel (2002), que afirma ter sido a cobiça e o ouro os motivos que conduziram os primeiros viajantes que chegaram à região para explorar e navegar pelos rios da Amazônia. Durante séculos, a Amazônia serviu como espaço privilegiado para expansão mercantilista.

Na trajetória de contato com a região, descrita por Castro (1997), na viagem em que a personagem central de 'A Selva' dirigia-se para o seringal no qual iria trabalhar, descortinava-se uma Amazônia grande, imensurável, da qual ele só conseguia vislumbrar as palmeiras, uma vez que estas se assemelhavam às de Portugal, sua terra natal; quando soube que as águas não eram do oceano, mas pertenciam à bacia hidrográfica da Amazônia, foi tomado de grande espanto pela grandiosidade do rio. Seus olhos não conseguiam penetrar na densa e fechada floresta, era como se houvesse uma cortina que lhe impedia a penetração, o ir mais além, mesmo estando muito próximo, não era possível, não conseguia vislumbrar a extensão e a profundidade da floresta.

Castro (1997), ao escrever seu relato de viagem, não consegue conter o espanto, não só diante do rio, mas de tudo o que naquele momento lhe enchia os olhos: a floresta, as margens, os barrancos e tudo mais que conseguia ver. Consoante à percepção apresentada, a floresta é para o homem "civilizado" da Europa um mistério, passível de ser desvendado somente pela própria natureza, mas o homem não habitante deste ambiente encontra dificuldade para entender. Não sendo esta a viagem dos sonhos da personagem, pois estava a caminho de um seringal para trabalhar, ainda assim, com todo o espanto, em alguns momentos parece exaltar $\mathrm{o}$ esplendor e a beleza da natureza vista do 'Justo Chermont' - barco em que viajava -, mesmo estando tomada pelo desejo de chegar logo ao lugar de destino.

A narrativa marcada por sua subjetividade, na qual os pensamentos da personagem parecem transmitir a perspectiva do autor, enfatiza que este era um contexto em germinação/formação, pois mesmo em sua feição majestosa era um mundo desordenado:

Ali tudo perdia as proporções normais [...]. A terra ia crescendo e a mata fechando-se cada vez mais [...]. Terra livre que se encontrasse, fora limpa a ferro e fogo pelo braço humano, no seu primeiro contato com a selva dominadora (p. 62).

Durante sua viagem a Amazônia, passa por diversas cidades pequenas da região, que, de acordo com suas observações, "[...] qualquer daquelas cidades, embora simpáticas na sua modéstia, não igualava sequer uma vila da Europa" (p. 52). O pensamento do autor é sempre de comparação e exaltação de sua terra natal, Portugal, que conhecia tão bem.

Para os viajantes que passavam pelo "Novo Mundo", um universo inédito se descortinava diferente dos padrões conhecidos de civilização, nada ou quase nada parecia coincidir com as terras européias, com o mundo que conheciam. De acordo com o pensamento de Castro (1997), os grandes rios de Portugal faziam-no sorrir diante do rio Amazonas. Não obstante a perplexidade com tantas novidades, o autor explicita, em determinado momento de suas interpretações sobre a região, uma visão da selva como prisão.

Para reforçar a imagem descrita sobre a Amazônia, o referido autor apresenta o testemunho de vários outros expedicionários. Em 1723, Francisco Melo Palheta nomeou um rio, conhecido como rio Madeira, devido ao perigo que os troncos das árvores, a princípio de aparência inofensiva, ofereciam às embarcações que 
cortavam suas águas próximo às margens para evitar os ricos ao navegar.

Após um longo período de viagem, chega ao seringal, onde consegue perceber apenas os contornos mais gerais do local no qual iria permanecer, e é tomado pela sensação de poder ver/sentir o coração da selva. A chegada ao barracão parecia fazer crescer cada vez mais a mata; as árvores pareciam se agigantar, umas sobre as outras, os olhos pareciam não conseguir comportar tamanha diversidade e grandeza, agora vistas de tão perto. À medida que caminhava para a cabana próxima no traçado da estrada de seringa em que deveria trabalhar, percebia os caules grossos e centenários.

As singularidades do novo contexto pareciam inesgotáveis, até mesmo a chegada da noite acontecia em tempo precoce, na selva escurecia muito rápido, o silêncio só era quebrado pelos barulhos dos animais, que eram percebidos por ele como rumores estranhos e imprecisos. Para ele, a selva era o elemento dominante de tudo o que se podia ver naquele espaço, o homem não passava de um transeunte em meio a um imenso enigma. Em seus relatos, ele compara a selva a um monstro, ao mesmo tempo em que narra de modo contínuo e contraditório suas belezas:

Daquela bárbara grandiosidade e da sua estranha beleza, uma só forte impressão ficava: a inicial, que nunca mais se esquecia e nunca mais também se voltava a sentir plenamente [...] contemplada por fora, sugeria vida liberta num mundo virgem $[. .$.$] ;$ vista por dentro, oprimia e fazia anelar a morte (p. 85).

Para o autor, a selva, ou o monstro como a denomina em alguns momentos, só mostra um ar menos furioso à luz do dia; quando iluminada causava menos terror, parecia mostrar parte do seu mistério. Para ele, os homens que ali eram obrigados a viver pareciam ficar cada vez mais embrutecidos; junto com a mata que os rodeava, tornavam-se tão selvagens quanto a floresta. Ele acreditava que os habitantes do local formavam um caldo de culturas e nem percebiam que eram prisioneiros e viviam em um cárcere.

Ao mesmo tempo em que Castro (1997) reconhece a beleza, a grandeza, magnitude e majestade da selva, afirma que tudo aquilo se constituiria em monotonia sem fim, com o passar do tempo. Toda aquela beleza já não mais importaria como no primeiro instante, se alguém tivesse que permanecer por muito tempo naquele local.

Tais relatos representam visões e percepções diferenciadas de um mesmo espaço físico-geográfico, nas quais se observa o quanto o olhar do outro, com referências socioculturais próprias, é ao mesmo tempo gerador de "novos" conceitos e formas de apreensão sobre determinada realidade.

Vale ressaltar que, para os habitantes da região, a floresta não se constituía e nem se constitui em prisão, pelo contrário, é vista como fonte de vida, de onde se pode garantir a existência por possibilitar a reprodução física e sociocultural, uma vez que ela fornece os alimentos, a caça, pesca, o roçado e a própria seringa; tudo isto é entendido como dádiva da natureza (Chaves, 1994).

Em relação às condições de manutenção e subsistência, dentre os vários relatos de viajantes, destacase o de Ferreira (1972), que descreve a imagem da floresta com grande abundância de alimentos. Este autor menciona que as árvores dão frutos sempre, pois, quando terminam umas, outras já estão frutificando, não sendo preciso plantálas ou cultivá-las, até porque não o saberiam, ou seja, a própria natureza se encarrega de fornecer às populações da região o alimento necessário para sua subsistência, mas a seu modo. Enquanto estivessem no período de cheia dos rios, era fácil caçar ou pescar sempre que fosse necessário; a abundância era tanta que não precisavam armazenar alimentos, pois a natureza, de uma forma ou de outra, sempre providenciava o necessário para o sustento da família e de todos que ali chegassem.

Por conseguinte, ambos os autores partilham a perspectiva, defendida em estudos atuais, de que a lógica de 
produção da população cabocla não se regia pela perspectiva mercantil. A comercialização do excedente para venda obedece prioritariamente às necessidades de subsistência, das relações de troca na cadeia de aviamento' ${ }^{1}$, das relações de compadrio, da prática de ajuda mútua, ou seja, as relações construídas sobre bases diferenciadas daquelas estabelecidas nos processos de produção urbano-industrial, sob a lógica do assalariamento e da acumulação.

Os olhos de Castro (1997, p. 101), por vezes, se embeveciam e pasmavam com a grandiosidade e a beleza imensurável da floresta Amazônica, outras vezes sentiam repulsa. Um dos locais que ele destaca é um pequeno lago, o qual é descrito como possuidor de uma forma muito bela, pois continha riquezas inigualáveis e escondia em suas águas peixes considerados nobres na região, descritos como possuidores de sabores admiráveis e, ao mesmo tempo, tão repugnantes. Ele também se espantava ao constatar que havia vida nos lagos, que considerava verdadeiros brejos. Assim, para os viajantes: "[...] O cenário metamorfoseava-se. O que era de longe beleza, concha de luz e moldura de policromo tela, era de perto fealdade e imundície".

Neste cenário, a natureza é percebida como portadora de ritmo próprio, criando e recriando suas condições de perpetuação. É interessante identificar nesta obra a visão do próprio caboclo sobre o processo de ocupação da Amazônia. O autor fala de Lourenço, caboclo nativo, um dos poucos, talvez o único, que não trabalhava nos seringais. Este via os imigrantes chegarem

[...], tão infelizes e desprotegidos, como diligentes e cobiçosos; via-os, com indiferença, ocuparem a terra dele, como se tudo aquilo lhes pertencesse e estivesse ali para seu regalo. Mas o tempo decorria e os que de começo, espalhavam energias, acabavam mostrando depauperamento; os que haviam trazido expressão de futuros vencedores, arrastavam-se depois como vencidos; e por um que regressava ao ponto de partida, quedavam ali, para sempre, centenas de outros, esfrangalhados, palúdicos, escravizados ou mortos. A selva não perdoava a quem pretendia abrir os seus arcanos e somente esse homem bronzeado, de cabelo liso e negro, que nascera já renunciando a tudo e se comprazia numa existência letárgica, junto de copiosas riquezas, encontrava nela vida fácil (Castro, 1997, p. 116).

Nesta fala, o autor apresenta o sentimento de posse vivenciado pelo caboclo da região, ao identificar os que chegavam de longe e aqueles que estavam ali tentando ocupar a sua terra, mas enganavam-se, pois em pouco tempo descobriam que a natureza não se deixava dominar.

É interessante destacar que os viajantes não conseguiam compreender como os caboclos lidavam com a floresta, com a natureza, pois, ao contemplarem o modus vivendi dos nativos da região, que parecia ser tão fácil para os que chegavam da Europa ou de outros lugares, percebiam o quanto era árdua a tarefa de sobreviver àquele contexto e, não raro, deparavam-se com barreiras intransponíveis às suas forças e habilidades.

Em seus relatos, ele descreve a dinâmica do clima na região e o espanto que lhe causava. No período de chuvas, ele contemplou o rio a encher e tornar-se um verdadeiro dilúvio, fato que acontecia todos os anos. As águas eram vindas do Peru ou da Bolívia e de muitos outros lugares. Por onde passavam, destruíam o que lhes estivesse a interromper a passagem, formando cachoeiras e movimentando águas, resultantes do verão, dantes paradas ou quase mortas. A terra ficava toda encharcada, em pouco tempo a selva parecia uma floresta submersa.

Os caboclos que durante o verão deixavam as canoas a quinhentos metros de distância das casas, agora as amarravam à porta. As casas, plantações e

\footnotetext{
A cadeia do aviamento, em seu formato original, estava fundada nas tradições de troca das sociedades indígenas, sendo redefinidas por novos parâmetros para favorecer a subordinação pela dívida praticada pelos seringalistas. Em seu novo perfil, a cadeia do aviamento passou a se caracterizar como um sistema de troca de produtos através de um vasto circuito que articulava os seringueiros num vínculo de dependência aos patrões nos seringais tradicionais e estes às Casas Aviadoras, nos centros urbanos (Manaus e Belém), que comercializavam com a indústria da Europa e dos EUA (Chaves, 1994, p. 10).
}

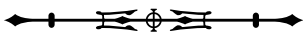


gados eram todos prejudicados no período de chuvas e mesmo as trilhas das seringueiras ficavam muitas vezes inundadas, impedindo que se tirasse látex para a produção da borracha.

As visões descritas sobre a mata expressam um tamanho espanto e perplexidade diante de todos os acontecimentos. Castro (1997) descreve uma tempestade, assistida por ele e Firmino, que ocorrem de forma soberana, colossal, assustadora e impiedosa:

Nunca Alberto vira, no mundo já trilhado, maior fúria dos elementos turbilhonantes. Sob as rajadas, a selva cada vez arfava mais, rangia por toda a parte e dir-se-ia prestes a destruir-se a si mesma no imenso clamor. Era fantástica e alucinante no sinistro ulular, a que só punha pausa o estampido do trovão, abalando toda a terra (p. 134).

Em certo sentido, e até certo ponto, estes relatos demonstram o quanto os fenômenos da natureza alteram e mesmo determinam o ritmo de vida dos homens na Amazônia.

Eram tantas as orquídeas que mais parecia um jardim suspenso composto pelas cores mais diversas e imagináveis. Assim, ele contempla a abundância e a variedade de orquídeas preciosas e de formas de vida dantes nunca vistas, que fascinavam e seduziam; ao mesmo tempo, aquilatava o valor monetário que alcançariam em Portugal. Simultaneamente, avaliava que havia ali tantos animais, em tamanha diversidade, que talvez nenhum caçador algum dia tenha imaginado existir sobre a face da terra e qualquer um deles se orgulharia em estar ali e conseguir pegar alguns, que poderiam ser considerados verdadeiros troféus.

O intercâmbio e a interdependência no e entre os ecossistemas foi registrado por ele ao contemplar as árvores que concediam vida aos parasitas que a elas se achegavam, numa troca constante, como se a terra ali existente não fosse o suficiente para o império vegetal.

Mesmo em meio a toda esta beleza descrita, o autor se sentia oprimido por aquele verde constante, que sufocava e tirava a esperança. Em alguns momentos, ele tinha a sensação de que sua vida era irrecuperável. Do ritmo monótono da chuva só ficava a sensação de impotência diante da mata que o cercava.

Pode-se encontrar uma similitude na abordagem de Ferreira (1972, p. 70), quando afirma que a visão que predomina em relação a Amazônia é a de "um país selvagem e sombrio, uma terra bruta e abandonada a si mesma; toda sua superfície está coberta de infinitas plantas de todas as famílias".

Assim como Castro, ele descreve um retrato da Amazônia como um lugar odioso aos viajantes que por ali têm que passar e relata que são inúmeras e odiosas as famílias dos insetos existentes na região. Afirma que só os índios são capazes de suportar e viver nesta região, pois estão habituados desde a infância, são parte integrante desta, por isso conseguem viver de forma "harmoniosa" com esta natureza, melhor ainda, conhecendo-a. Assim, pode-se dizer que Amazônia não é somente um ambiente físico, mas humano e social ao mesmo tempo, o que revela uma diversidade socioambiental e cultural rica e diversa.

Outrossim, em que pese o etnocentrismo marcante, estes relatos de viagem revelam a riqueza da biodiversidade existente na Amazônia ainda não conhecida pelo homem em sua totalidade e, ao mesmo tempo em que chamam atenção, neste cenário, para as habilidades das populações amazônidas em lidar com a natureza, conhecendo-a pela proximidade, pela vivência com esta, a partir do estabelecimento de suas relações sob forma diferenciada, as quais têm suas bases em valores e padrões construídos e estabelecidos ao longo de suas trajetórias sociohistórica e cultural expressas nas formas de manejo e de adaptação ao ambiente que os circunda do qual se sentem pertencentes.

\section{Relações sociais na Amazônia na obra de Ferreira de Castro}

Atreito a vida sedentária, o caboclo não conhecia as ambições que agitavam os outros homens, já Alberto o soubera em Belém. A mata era sua. A terra enorme pertencia-lhe, senão de direito, por 
moral, por ancestralidade, da foz dos grandes rios às cabeceiras longínquas. Mas ele não a cultivava e quase desconhecia o sentimento de posse. Generoso na sua pobreza, magnífico na humildade, entregava esse solo fecundo, pletórico de riquezas, à voracidade dos estranhos [...] (p. 46).

Para tratar sobre as relações estabelecidas socialmente na Amazônia nos marcos da história da região, faz-se necessário focalizar a trama das relações das populações tradicionais em suas singularidades. Para tal, é necessário perceber, através de uma leitura crítica, a influência dos vários povos, raças e etnias que aportaram nesta região e que, direta ou indiretamente, influenciam a cultura amazônica como um todo, alterando hábitos e costumes, ao passo que também sofreram mudanças e influências pelo contato com a população da região.

As formas de relações sociais estabelecidas na Amazônia no período tratado por Castro (décadas de 1910 e 1920) ancoravam suas bases na exportação da seringa. Este era um produto nativo da região, no qual o trabalho empreendido era a sua extração e preparo para comercialização.

Muitos portugueses, sabendo da demanda pelo produto no mercado europeu, vieram para Amazônia, onde montaram as chamadas casas aviadoras, local em que se comercializava a seringa. No entanto, para o trabalho no interior dos seringais, na coleta do látex, os nordestinos eram convocados sob promessa de conquista, prometendo-se a estes riqueza fácil e retorno garantido para sua terra. Esta estratégia foi adotada uma vez que os seringalistas e capatazes não conseguiam domesticar os índios para os trabalhos forçados. Assim, na esperança de conseguir alcançar o sonho da riqueza, muitos nordestinos aventuraram-se em vir para a Amazônia. As condições de viagem dos nordestinos nos navios era a pior possível, vinham geralmente no convés, local úmido, sujo e escorregadio.

Castro (1997), português de origem que estava em Belém em casa de um tio por problemas políticos em seu país, foi mandado para um seringal na Amazônia. Teve que viajar com os nordestinos que iriam trabalhar também nos seringais. Angustiava-se com aquela situação, não conseguia entender a calma dos nordestinos e tinha a impressão de que só ele estava sofrendo. Pensava consigo mesmo que os nordestinos não tinham sequer alma, pois se conformavam com aquela situação com tamanha facilidade. Impressionava-se e chegava mesmo a sentir desprezo por aquelas pessoas.

Diante da situação, questionava-se quanto ao tipo de sentimento que porventura aqueles nordestinos trariam no peito, para que se colocassem naquela situação, mais ainda, que se satisfizessem com tão pouco que lhes era dado. Ele percebia entre eles um forte sentimento de união que talvez encontrasse explicação nas experiências de dor e de fome tão semelhantes a todos os nordestinos. Era possível que isto os fizesse solidários uns com os outros. $O$ autor, na verdade, considerava-se melhor que aquelas pessoas, um rapaz português, que havia iniciado os estudos de nível superior em direito, não concluindo por problemas políticos, não poderia estar ele naquela situação junto àqueles nordestinos; mas estava e tinha que lidar com a situação na qual se encontrava. Não conseguia aceitar o conformismo daquelas pessoas ante a tal condição de humilhação e privação.

Depois da longa viagem, chegou ao seringal onde iria trabalhar, não sabia dizer por quanto tempo. Havia uma pequena recepção dos que ali estavam há algum tempo e a chegada de novos legionários do Ceará e do Maranhão era sempre motivo de riso para aqueles, pois sabiam o que aguardava os novos seringueiros.

Nos seringais havia os barracões, onde o nordestino ao chegar já tinha uma dívida - o valor da sua passagem, a comida que comeu no barco durante a viagem e todas as despesas mais que tivesse feito - e para entrar no seringal precisava-se de um mínimo de mantimentos, ferramentas e uma espingarda, o que lhes aumentava mais ainda a dívida com o dono do barracão. Todos deveriam se dirigir ao barracão para pegar mantimentos, ferramentas e orientações de como proceder a partir daquele momento. Em geral, agrupavam um "cabra" já experiente nas trilhas do seringal para ficar com um novato, apelidado de "brabo". 
O desejo de voltar a sua terra os fazia agüentar todo tipo de humilhação e trabalho duro, na tentativa de pagar a sua dívida e retornar à sua terra natal com algum dinheiro, sonho impossível para a maioria.

As trilhas dos seringais eram visitadas, vez por outra, por capatazes do barracão, para ver se os homens estavam trabalhando mesmo, se não estavam fazendo "corpo mole" para não tirar seringa, pois tinham que trabalhar de sol a sol para pagar o que deviam ao dono do seringal, mas nunca o conseguiam, pois o preço de tudo quanto necessitavam para sobreviver na selva era muito caro e tinha que ser pago com a produção da borracha que conseguiam recolher na semana de trabalho; se esta não fosse boa, eles sequer conseguiam pegar a farinha e o jabá para comer. Um agravante de toda esta realidade era a oscilação do preço da borracha no mercado internacional. Devido às plantações de borracha fora do Brasil, isto fazia com que os preços diminuíssem e o seringueiro tinha que vender a borracha mais barata ao dono do seringal, desse modo, nunca conseguia pagar a dívida contraída.

As relações sociais estabelecidas no seringal eram tipicamente de exploração, do dono do seringal para com os seringueiros que ali chegavam com esperanças de enriquecimento "fácil". Esta realidade das relações estabelecidas dentro do seringal é descrita por Firmino, que fazia uma análise da realidade que o circundava e tinha uma explicação de porquê não havia mulheres dentro do seringal.

Seu Juca é quem manda buscar os 'brabos' ao Ceará e lhes paga as passagens e as comedorias até aqui. Se eles viessem com as mulheres e a filharada, ficavam muito caros. Depois, se um homem tivesse aqui a família, trabalhava menos para o patrão. la caçar, ia pescar, ia tratar do mandiocal e só tirava seringa para algum litro de cachaça $[\ldots] \bigcirc$ que seu Juca quer é seringueiro sozinho, que trabalha muito com a idéia de tirar saldo para ir ver a mulher ou casar lá no Ceará (p. 103).

Esta explicação revela como eram estabelecidas as relações de produção no seringal, dentro de uma lógica pensada para o desenvolvimento das atividades produtivas no contexto do mercado da borracha.

Mas, para além destas relações de produção, os imigrantes que sofriam longe de sua terra e família ainda conseguiam fazer festa. Interessante destacar que estas refletiam o emaranhado de culturas presentes naquele momento na região, pois o autor relata que misturavam ritmos nordestinos, caboclos, indígenas, entre outros. As festas aconteciam na casa do caboclo Firmino, nativo da região e único que não trabalhava nos seringais. $\mathrm{Na}$ verdade, a casa era larga, com alpendre, de terra batida, com uns velhos caixotes e pequenos troncos de madeira espalhados para o assento dos convidados. O som era retirado de um acordeão, tocado por um dos participantes da festa que soubesse manusear o instrumento.

As festas aconteciam quando o caboclo Firmino conseguia pegar peixes grandes e em grande quantidade. Para comemorar a pesca, oferecia festa e chamava os nordestinos para participarem. A abundância na caça e pesca representa uma dádiva da natureza para com o homem, por isso a festa para comemorar era feita com tão grande fartura. Nestas ocasiões era possível perceber, ainda, as relações de gênero que se estabeleciam, quais eram os códigos culturais que regiam a relação homemmulher no seringal, enquanto resultado de uma construção social vivenciada pelos que ali moravam. Nas festas havia presença de poucas mulheres, as que ali se encontravam tinham acompanhantes e não poderiam ser importunadas pelos nordestinos que estavam sozinhos, o que era uma espécie de lei, regra para os participantes da festa.

As festas constituíam-se em organização para a realidade dos seringais, eram ainda o que proporcionava momentos de descontração únicos para quem se sentia prisioneiro daquele local; era um momento de fuga simbólica para os homens daquele lugar, ainda que pela manhã, ao término da festa, todos tivessem que voltar aos seringais e à rotina de trabalho.

Castro (1997), em determinados momentos, vê refletido na floresta o ódio que sente pelos seus algozes, 
assim, não consegue ver algo que seja verdadeiramente bom naquele local. Na verdade, também enfrenta momentos em que delineia pontos de identificação com a floresta, ou pelo menos indica que gostaria de tê-los.

$\bigcirc$ referido autor, sob a roupagem de seus personagens, em seu discernimento compreende que a imponência da floresta está associada à insubmissão desta à vontade humana:

[...] era um mundo à parte, terra embrionária, geradora de assombros e tirânica, tirânica! Nunca árvore alguma daquelas the dera uma sugestão de beleza, levando-lhe ao espírito as grandes volúpias íntimas. Ali não existia mesmo a árvore. Existia o emaranhado vegetal, louco, desorientado, voraz, com alma e garras de fera esfomeada... Era a grande muralha verde e era a guarda avançada dos arbustos que vinham crescer ao redor da cacimba e, degolados pelo terçado de Firmino, brotavam de novo, numa teima absurda e alucinante. A selva não aceitava nenhuma clareira que lhe abrissem e só descansaria quando a fechasse novamente, ....! A ameaça andava no ar que se respirava, na terra que se pisava, na água que se bebia, por que ali somente a selva tinha vontade e imperava despoticamente. Os homens eram títeres manejados por aquela força oculta, que eles julgavam, ilusoriamente, ter vencido com a sua actividade, o seu sacrifício e a sua ambição (p. 123).

Este relato revela diversas nuances da constante luta do homem para dominar a natureza, a qual é atribuída vontade própria, de não subordinação à vontade humana. A desordem da floresta, descrita pelo autor, revela pontos do olhar e leitura realizada sob os dilemas de sua cultura, tendo em vista que a participação dos atores sociais toma como referência os parâmetros estabelecidos social e culturalmente, pela adoção de uma visão etnocêntrica determinada por sua realidade de origem, sendo quase sempre ponto de referência em contraposição a tudo que pudesse existir fora desta. Ao mesmo tempo em que não consegue ignorar por completo o que vê de belo no coração da selva, parece nutrir dentro de si um misto de raiva e admiração por aquele local que, não obstante toda exuberância contemplada constituir-se em grilhões, consegue descortinar as expressões de liberdade da natureza. Ao passo que o mesmo sente suas forças sendo exauridas e sua autonomia cerceada.

Este é um momento importante na sua obra que convida à reflexão. $O$ autor relata o que é a liberdade, seu sentido para quem já foi escravo, em que as atitudes podem ser inesperadas, à vista de quem nunca levou uma chibatada. O sentido da liberdade partindo da experiência concreta de um escravo talvez seja o que de mais inusitado percebeu o autor, num local onde tudo parecia aprisioná-lo, como alguém poderia pensar em ser livre naquele espaço e, mais ainda, considerar que era totalmente livre em meio à selva. $\bigcirc$ autor encontra um negro ex-escravo que relata o que significa a liberdade para ele que teve como condição, em determinado período da sua vida, o ser escravo:

\begin{abstract}
Mas seu Juca se desviou... Estava a escravizar os seringueiros. Tronco e peixe-boi no lombo, só nas senzalas. E já não há escravatura... Não foi por ti nem pelos outros como tu que perdi a minha alma e vou para o inferno! Foi porque seu Juca te fez escravo e aos outros safados que te acompanham. Se estivesse no tronco, como tu, o feitor que me batia lá no Maranhão, eu também matava a seu Juca. Negro é livre! O homem é livre! (p. 219).
\end{abstract}

A liberdade não deve ser privilégio de alguns e no falar do ex-escravo, o negro é livre, todo homem deve ser livre. Interessante notar que para quem já viveu como escravo, em senzalas, a natureza não se constituía em cadeia, prisão ou inferno, a ausência de liberdade caracterizava-se pela subordinação do trabalhador no seringal, esta sim podia ser considerada como condição de supressão de liberdade para o homem.

Passado algum tempo na trilha de seringal, o autor tem a oportunidade de passar a viver no barracão. A simples idéia de deixar a trilha para ficar no barracão o fazia se sentir mais próximo da "civilização", embora soubesse que estava muito longe dali o que considerava civilização. A antiga barraca tinha agora um outro sentido, ficaria por muito pouco tempo nela, a floresta perdia a influência de 
muralha verde que antes exercia sobre ele. No barracão, ele passou a se sentir no "paraíso", sua nova moradia. Mesmo com toda diferença entre a casa em que morava antes e as novas instalações, ainda estavam presentes os diversos insetos que enchem a floresta, havia ainda as cobras que se constituíam em verdadeiras ameaças para qualquer pessoa que ali fosse residir. Para ele, a selva parecia alimentar aqueles insetos e répteis como forma de defesa própria, eram verdadeiras legiões que ninguém conseguiria exterminar ou identificar.

$\mathrm{Na}$ perspectiva posta pelo autor, havia uma forte determinação do meio geográfico ao contexto sociocultural, assim como as plantações que, apesar da fertilidade do solo, eram devoradas por formigas e por outros insetos. Era como se a selva não admitisse outro modo de vida que não o seu próprio, apenas a sua vontade poderia imperar naquele local.

Nas descrições adotadas pelo autor, destacam-se a magnitude e a soberania da natureza sobre qualquer outra forma de domínio possível. A leitura é sempre de impotência do homem perante a natureza e a forma de vê-la naquele momento; em certa medida, estava vinculada à condição vivenciada pela personagem que assumiu, ou seja, de trabalhador no seringal. Assim, o autor efetiva a transferência do sentimento de subordinação, que predomina nas relações de produção que o escravizam, para a floresta. Portanto, tendo em vista a necessidade de ter que lidar com ela, sem, todavia, conseguir visualizar formas de dominá-la ou submetê-la à sua vontade, seu maior desafio era a sobrevivência naquele meio hostil, atribuindo a ela a causa de sua prisão e transformando-a em sua inimiga.

Ainda que dominado por esta perspectiva, em diversos momentos o autor faz algumas análises críticas da situação de subordinação dos seringueiros que ali se encontravam, destacando as contradições e injustiças presentes no seringal. Todavia, atribui toda culpa das injustiças, ou parte dela, à natureza, em que o homem não se pertencia a si mesmo, como potência vegetal implacável que se aliava a do amo para oprimir aos demais. Por todo tempo em que esteve naquele local, a selva era o cárcere sem porta onde todos os homens estavam presos e as feras caminhavam livremente.

Para muitos expedicionários, o preço de desbravar o novo mundo foi a própria vida. Para eles, a "selva" tinha vida, rugia e os animais e feras ali existentes não poderiam ser comparados aos encontrados na África. É importante destacar que, apesar de todas estas descrições sobre a Amazônia, vista como uma selva, a busca pelas riquezas existentes na região fazia homens se arriscarem de forma não menos determinada e cada vez em maior escala, os quais deixaram suas marcas violadoras na "selva" e que podem ser percebidas mesmo depois de muitos séculos passados.

A visão exógena adentra e perpetra a própria percepção da população local, que produz e reproduz, em determinados momentos, esta forma de interpretar seu ambiente, a natureza que o envolve. Por vezes, a interpretação do estrangeiro produz juízos de valores depreciativos sobre as modalidades de organização local e não raro são atribuídas características como a preguiça, indolência e falta de ambição, se comparados a outros povos, atribuições que impõe uma posição de subalternidade e aprisiona numa armadilha os povos locais.

Todavia, vale ressaltar que há muitas formas de resistência às sobredeterminações externas, seja das formas de produção, seja dos paradigmas racionais. Assim, é possível identificar diversos grupos locais com identidades sociais demarcadas pela dinâmica local, bem como pela conservação dinâmica de saberes tradicionais.

Nos primeiros anos de produção da borracha, muitos donos de barracão e casas aviadoras conseguiram ficar ricos. Até que

Um dia, porém, a hevea brasiliensis, levada subrepticamente por mãos britânicas, desdobrara a sua nacionalidade, [...] Ferida pela emigrada, a borracha da Amazônia deixara de ser meio de elásticas fortunas, limitando a perspectiva das ambições (p. 32). 


\section{CONSIDERAÇÕES FINAIS}

A obra de Castro (1997) representa, sem dúvida, uma contribuição significativa no processo de formação do pensamento social na Amazônia e sobre a Amazônia, não só pela beleza de seu romance, mas principalmente pela riqueza de detalhes captados por ele quando da sua estada na região. Assim, esta obra pode ser estudada do ponto de vista da Antropologia Cultural e da Etnoecologia ou por outras disciplinas e áreas da ciência.

Em sua narrativa faz-se necessário identificar as formas singulares de organização social e cultural das populações tradicionais da Amazônia. Sua produção singular apresenta uma interpretação e a construção de um sentido de Amazônia diferente do conhecido e construído pela população cabocla, ribeirinha, indígena, e tantos outros povos e etnias que compõem e vivem na Amazônia, haja vista que seu romance constitui um outro olhar de como se configuram as relações internas à região. No período histórico relatado, as relações sociais estavam cingidas pela produção e comercialização da borracha e no embrionário processo de inserção da região nas relações comerciais de produção no mundo capitalista.

Numa visão diametralmente diferente da relatada por Castro, para os povos da Amazônia, a natureza é vista como mãe, no sentido daquela que cuida, protege e nutre, pois proporciona o necessário para a reprodução da vida. Os rios dão o peixe, a terra firme lhes proporciona as frutas, legumes, vinhos e remédios para cura das doenças. A própria natureza fornece o alimento e a cura para o corpo, para isso bastava conhecê-la e identificar seus segredos. São leituras e perspectivas diferenciadas de um mesmo espaço físico-geográfico, de uma mesma natureza, a partir de óticas diferenciadas.

É importante ressaltar que o seu olhar é apenas um dos muitos lançados sobre a região amazônica ao longo da história, pois, tais obras apresentam uma visão exógena da região e das relações sociais vigentes, sob o signo da cultura daquele que pertence a um contexto sociocultural diferenciado do vivido pelo povo amazônida. Portanto, representam interpretações e olhares sobre a população, a floresta, os hábitos e costumes regionais a partir da ótica dos atores de origem externa à região que preconizam a necessidade de domínio do homem sobre a natureza. Tal perspectiva encontra amparo e força na visão cartesiana da Ciência Moderna, que busca subordinar a natureza aos determinantes da Ciência e da Tecnologia, orientada para a expansão e valorização do capital.

Desse modo, em que pese a relevância, as leituras e estudos hoje em curso precisam avançar e (re)construir a imagem da Amazônia fundada com bases em relatos como os de Castro (1997) e outros, que viam a Amazônia como eldorado perdido, inferno verde e selva. Estas idéias prevaleceram e, até certo ponto, ainda se fazem presentes no discurso e prática das pessoas da região, bem como de outros povos e culturas que olham e interpretam a Amazônia apenas a partir da lógica de sua própria cultura, que não raro são marcados por conflitos de interesses e choques entre valores culturais diferenciados. A Amazônia, uma das áreas de maior biodiversidade do planeta, serve de tema para muitos estudos, pesquisas, discussões e trabalhos, no entanto, ainda é vista por muitos como lugar de mistérios, mitos e lendas até então não completamente desvendados pelo homem.

Embora seja verdadeiro que muito ainda precisa ser desvendado sobre a realidade amazônica, o desafio mais importante que se apresenta é fazer, na atualidade, uma leitura realista da pluralidade de identidades, da cultura regional em suas características e particularidades que precisam ser respeitadas e dos dilemas postos para a região pela dinâmica da sociedade global.

\section{REFERÊNCIAS}

CASTRO, Ferreira de. A Selva. 37. ed. Lisboa: Guimarães Ed., 1997.

CHAVES, Maria do Perpétuo S. R. De "cativo" a "liberto": o processo de constituição sócio-histórica dos seringueiros no Amazonas, 1994. Dissertação (Mestrado em Sociologia Rural) Universidade Federal da Parába, 1994. 
DANIEL, João, Pe. O Tesouro descoberto no máximo rio Amazonas. Belém: Contraponto, 2002

FERREIRA, Alexandre R. Viagem filosófica pelas capitanias do Grão Pará, Rio Negro, Mato Grosso e Cuiabá: memórias - zoologia/ botânica. Brasília: Conselho Federal de Cultura, 1972.
WAGLEY, Charles. Uma comunidade amazônica: estudo do homem nos trópicos. 3. ed. Tradução de Clotilde da Silva Costa. Belo Horizonte: Itatiaia; São Paulo: EDUSP, 1988.

Recebido: $27 / 07 / 2006$ Aprovado: 23/04/2007 